\title{
DINAMIKA ISLAM KULTURAL: Studi atas Dialektika Islam dan Budaya Lokal Madura
}

\author{
Paisun \\ STIKA Annuqoyyah Guluk-Guluk Sumenep. Jalan Raya Prenduan Sumenep. Telp. 087850276785
}

Abstract

Throughout the history, it is well-known that the ingress and the progress of Islam in Indonesia, especially in Java and Madura, were held almost without any tension and conflict. Even in the societies with some former belief systems such as Animism and Buddhism, Islam was easily accepted as a religion that brings peace within its teachings. During periods, Islam and local cultures perform a dialectical relationship and give rise to local variances of Islam, such as Javanese Islam, Madurese Islam, Sasak Islam, Sundanese Islam, etc. Those variances of Islam are the result of an acculturation process between Islam with the local cultures. In other word, this process is also called as "inculturation". These local variances of Islam, further termed as the "cultural Islam" in this paper, have become a characteristics of Indonesian Islamic societies phenomenon which are different from Middle-East's Islamic society and European Islamic society. This paper discusses about the Madurese Islam, one of these cultural Islam's variances. Dialectical process between Islam and the local culture of Madura in turn generates a unique Madurese Islam, which is distinctive and esoteric. In its further developments, Islam and Madurese tradition are seen as unity and 
inseparatable, though people can still distinguish one another. This study seeks to uncover and expose the Islamic cultural dynamics that exist and grow in Madura: how big is the change that occurred, in which part, and what factors underlie these changes. This study provides benefit in enriching our scientific study about Indonesian cultural heritage, especially about the dialectical relationship between Islam and Madurese local culture.

Key words: Cultural Islam, Madura, dialectical relationship, dynamic changes

\section{Pendahuluan}

Menilik sejarah Islam Indonesia, kita dapat melihat bahwa Islam masuk dan menyebar di Jawa dan Madura nyaris tanpa ada ketegangan dan konflik (Al Humaidy, 2007: 278). Islam dengan mudah diterima oleh masyarakat sebagai sebuah agama yang membawa kedamaian, sekalipun kala itu masyarakat sudah mempunyai sistem kepercayaan tersendiri, baik berupa animisme maupun agama Hindu-Budha. Ada beberapa hal yang digunakan sejarawan untuk mendukung tesis tersebut. Pertama, kepatuhan orang Jawa dan Madura kepada pemimpin agama, politik, dan ekonomi yang relatif tanpa sikap kritik dan kontrol menyebabkan penyebaran Islam berjalan dengan mulus tanpa ketegangan. Sebab, penyebaran Islam selain dilakukan oleh pemimpin agama, juga dinahkodai oleh pemimpin politik dan ekonomi. Bahkan, para wali sendiri merupakan elite politik dan ekonomi yang mampu menembus relung-relung kebudayaan dan orang Jawa dan Madura (Azra, 1982: 2).

Kedua, adanya unsur kesamaan antara ajaran Islam yang bernuansa sufistik dan ilmu kebatinan Jawa (Baso, 2010: www.konspirasi.com). Ketiga, proses penyebaran Islam melewati jalan kultural. Para pendakwah Islam dulu, memang lebih luwes dan halus dalam menyampaikan ajaran Islam kepada masyarakat yang heterogen setting nilai budayanya. Wali Songo dapat dengan mudah memasukkan Islam karena agama tersebut tidak dibawa dalam bungkus Arab, melainkan dalam racikan dan kemasan bercita rasa Jawa. Artinya, masyarakat diberi "bingkisan" yang dibungkus budaya Jawa tetapi isinya Islam.

Islam yang berdialektika dengan budaya lokal tersebut pada akhirnya membentuk sebuah varian Islam yang khas dan unik, seperti Islam Jawa, 
Islam Madura, Islam Sasak, Islam Minang, Islam Sunda, dan seterusnya. Varian Islam tersebut bukanlah Islam yang tercerabut dari akar kemurniannya, tapi Islam yang di dalamnya telah berakulturasi dengan budaya lokal. Dalam istilah lain, telah terjadi inkulturasi. Dalam studi kebudayaan lokal, inkulturasi mengandaikan sebuah proses internalisasi sebuah ajaran baru ke dalam konteks kebudayaan lokal dalam bentuk akomodasi atau adaptasi. Inkulturasi dilakukan dalam rangka mempertahankan identitas. Dengan demikian, Islam tetap tidak tercerabut akar ideologisnya, demikian pun dengan budaya lokal tidak lantas hilang dengan masuknya Islam di dalamnya.

Varian Islam lokal tersebut, untuk selanjutnya penulis menyebutnya Islam kultural terus lestari dan mengalami perkembangan di berbagai sisi. Islam Kultural tetap menjadi ciri khas dari fenonena keislaman masyarakat Indonesia yang berbeda dengan Islam yang ada di Timur Tengah, maupun Eropa. Hal ini tidak lepas dari heterogenitas dan kemajemukan bangsa Indonesia yang tidak dimiliki oleh bangsa mana pun di dunia. Sebagaimana mafhum, Indonesia sebagai negara plural, tidak hanya beragam dari segi agama, keyakinan, budaya, suku bangsa dan juga bahasa. Negeri ini juga multietnik (Dayak, Kutai, Banjar, Makassar, Bugis, Jawa, Madura, Sunda, Batak, Aceh, Minang, Flores, Bali dan seterusnya) dan juga menjadi medan pertarungan berbagai pengaruh multimental dan ideologi (India, Cina, Belanda, Portugis, Hinduisme, Budhisme, Konfuisme, Islam, Kristen, Kapitalisme, sosialisme dan seterusnya) (Aziz: 2009: 24). Heterogenitas dan kemajemukan bangsa tersebut pada gilirannya menempatkan Indonesia sebagai negara yang unik, khas, dan menarik. Demikian pun dengan pola keberagamaan yang dianutnya. Agama yang tumbuh dan berkembang di Indonesia mau tidak mau harus berdialektika dengan budaya lokal yang kemudian mempunyai ciri khas dan keunikan tersendiri.

Islam Madura merupakan salah satu varian Islam kultural yang ada di Indonesia setelah terjadinya dialektika antara Islam dengan budaya Madura. Proses dialektika tersebut pada gilirannya menghasilkan Islam Madura yang unik, khas dan esoteris dengan ragamnya tradisi-tradisi Madura yang sudah disisipi nilai-nilai Islam. Pada perkembangan selanjutnya, Islam dan tradisi Madura menjadi satu kesatuan yang tidak dapat dipisahkan meski masih dapat dibedakan satu sama lain.

Tradisi Madura yang Islami tersebut terpelihara kelestariannya hingga kini. Namun bukan berarti, tanpa perubahan sama sekali. Di berbagai sisi, 
terdapat beberapa perubahan yang menunjukkan adanya dinamisasi Islam kultural yang tumbuh dan berkembang di Madura. Sebab, pada dasarnya perubahan memang suatu hal yang niscaya. Hal ini dapat dipahami lantaran tak ada yang stagnan di dunia ini. Perubahan senantiasa terjadi hampir pada semua ruang kehidupan manusia, baik menyangkut persoalan politik, sosial, budaya, maupun ekonomi. Perubahan dimaksud bisa dilatari oleh perkembangan pengetahuan yang dimiliki oleh manusia ataupun lingkungan yang mengitarinya yang kemudian dapat mempengaruhi kehidupan manusia tersebut.

Kajian ini berupaya untuk mengungkap dan memaparkan dinamika Islam kultural yang ada, tumbuh, dan berkembang di Madura. Seberapa besar perubahan yang terjadi, di bagian mana saja, dan faktor apa yang melatari perubahan tersebut. Dari kajian ini diharapkan dapat memberikan manfaat dan memperkaya khazanah keilmuan kita, khususnya yang membahas dialektika antara Islam dan budaya lokal Madura.

\section{Agama dan Budaya: Kerangka Konseptual}

Dalam kaitannya dengan manusia, agama seyogyanya tidak dipahami sebagai seperangkat doktrin dan sistem moral an sich, yang terpisah dari manusia. Agama, sebagaimana dipahami Zamakhsyari Dhofier dan Abdurrahman Wahid, tidak mengandung nilai-nilai dalam dirinya, tetapi mengandung ajaran-ajaran yang menanamkan nilai-nilai sosial pada penganutnya, sehingga ajaran-ajaran agama tersebut merupakan salah satu elemen yang membentuk sistem nilai budaya (Dhofier, dkk., 1978: 27). Dalam kerangka ini, agama memberikan sumbangsih yang signifikan dalam sistem moral maupun sosial masyarakat. Nilai-nilai agama dijadikan pedoman dalam berbagai tindakan dan pola perilaku manusia. Sehingga, pada perkembangannya, nilai-nilai agama dikonstruk oleh penganutnya menjadi nilai-nilai budaya, yang dipakai dan dipraktikkan dalam kehidupan masyarakat dimaksud.

Lebih eksplisit dari itu, Geertz memahami agama sebagai sistem kebudayaan (Syam, 2007: 11-13). Sementara kebudayaan, dalam pandangan Geertz didefinisikan sebagai pola bagi kelakuan yang terdiri dari serangkaian aturan-aturan, resep-resep, rencana-rencana dan petunjuk-petunjuk yang digunakan manusia untuk mengatur tingkah lakunya. Kebudayaan dengan demikian juga dilihat pengorganisasian pengertian-pengertian yang tersimpul dalam simbol-simbol yang berkaitan dengan ekspresi manusia 
(Al Humaidy, 2007: 278). Karena itu, Geertz kemudian memahami agama tidak saja sebagai seperangkat nilai di luar manusia, tapi juga merupakan sistem pengetahuan dan sistem simbol yang memungkinkan terjadinya pemaknaan (Syam, 2007: 13).

Sebagai sistem pengetahuan, agama merupakan sistem keyakinan yang sarat dengan ajaran-ajaran moral dan petunjuk kehidupan (baca: Wahyu) yang harus dipelajari, ditelaah dan kemudian dipraktikkan oleh manusia dalam kehidupannya. Dalam hal ini, agama memberikan petunjuk mengenai yang baik dan buruk, yang pantas dan tidak pantas, dan yang tepat dan tidak tepat. Nilai-nilai agama dapat membentuk dan mengkonstrukkan perilaku manusia dalam kesehariannya.

Sementara agama sebagai sistem simbol, terdapat simbol-simbol tertentu untuk mengaktualisasikan ajaran agama yang dianutnya. Baik simbol-simbol dimaksud berupa perbuatan, kata-kata, benda, sastra dan sebagainya. Sujud misalnya, merupakan sebentuk simbolisasi atas kepasrahan dan penghambaan penganutnya pada pencipta. Sujud merupakan simbol totalitas kepasrahan hamba, dan pengakuan secara sadar akan kemahabesaran Allah SWT. Dalam hal ini, sujud yang terdapat dalam shalat merupakan bagian dari ritual keagamaan dalam kehidupan masyarakat beragama ( $\mathrm{Al}$ Humaidy, 2007: 282-284).

Dari itu dapat dipahami bahwa antara kebudayaan dan agama, masing-masing mempunyai simbol-simbol dan nilai tersendiri. Agama adalah simbol yang melambangkan nilai ketaatan kepada Tuhan. Kebudayaan juga mengandung nilai dan simbol supaya manusia bisa hidup didalamnya. Agama memerlukan sistem simbol, dengan kata lain agama memerlukan kebudayaan agama. Tetapi keduanya perlu dibedakan. Agama adalah sesuatu yang final, universal, abadi (parennial) dan tidak mengenal perubahan (absolut). Sedangkan kebudayaan bersifat partikular, relatif dan temporer. Agama tanpa kebudayaan memang dapat berkembang sebagai agama pribadi, tetapi tanpa kebudayaan agama sebagai kolektivitas tidak akan mendapat tempat (Kuntowijoyo, 2001: 196).

Dengan demikian, dialektika antara agama dan kebudayaan merupakan sebuah keniscayaan. Agama memberikan warna (spirit) pada kebudayaan, sedangkan kebudayaan memberi kekayaan terhadap agama. Hal inilah yang terjadi dalam dinamika keislaman yang terjadi di Indonesia, khususnya di Jawa dan di Madura, yang akan diulas berikut ini. 


\section{Islam dan Budaya Lokal: Keniscayaan Dialog}

Sebagaimana mafhum, Islam adalah agama universal, yang tidak dikhususkan pada umat dan bangsa tertentu sebagaimana agama-agama samawi sebelumnya. Islam merupakan agama paripurna di antara beberapa agama yang telah diturunkan oleh Allah SWT kepada para nabi dan utusanNya. Misi utama Islam adalah rahamatan lil alamin, membawa kedamaian kepada seluruh alam. Dengan misi ini, Islam disebarkan ke seluruh dunia, termasuk Indonesia.

Peyebaran Islam ke berbagai wilayah di dunia ini, menyebabkan corak dan varian Islam memiliki kekhasan dan keunikan tersendiri daripada Islam yang berkembang di Jazirah Arab. Hal ini dapat dipahami karena setiap agama, tak terkecuali Islam, tidak bisa lepas dari realitas di mana ia berada. Islam bukanlah agama yang lahir dalam ruang yang hampa budaya. Antara Islam dan realitas, meniscayakan adanya dialog yang terus berlangsung secara dinamis (Thahir, 2007: 174).

Demikian pun saat Islam menyebar ke Indonesia, Islam tidak bisa lepas dari budaya lokal yang sudah ada dalam masyarakat. Antar keduanya meniscayakan adanya dialog kreatif dan dinamis, hingga kemudian Islam dapat diterima sebagai agama baru tanpa harus menggusur budaya lokal yang sudah ada. Dalam posisi ini, budaya lokal yang mewujud dalam tradisi dan adat masyarakat setempat, tetap dapat dilakukan tanpa harus mencederai ajaran Islam, sebaliknya Islam tetap bisa diajarkan tanpa harus mengganggu harmoni tradisi masyarakat.

Dialog kreatif antara Islam dan budaya lokal tidaklah berarti mengorbankan Islam, dan menempatkan Islam kultural, sebagai hasil dari dialog tersebut, sebagai jenis Islam yang rendahan dan tidak bersesuaian dengan Islam yang "murni", yang ada dan berkembang di Jazirah Arab (Geertz, 1981: 170). Tapi Islam kultural harus dilihat sebagai sebentuk varian Islam yang sudah berdialektika dengan realitas di mana Islam berada dan berkembang. Menjadi Islam, tidak harus menjadi Arab. Islam memang lahir di Arab, tetapi tidak hanya untuk bangsa Arab. Proyek Arabisme merupakan proyek politik yang berkedok purifikasi Islam, yang berusaha menjadikan Islam sebagai sesuatu yang tunggal dan seragam (Wahid, 2009: 19-20).

Dalam pemahaman mereka, Islam kaffah adalah Islam yang ada dan berkembang di Arab, sehingga seluruh komunitas Islam harus mengikuti pola keberagamaan dan keyakinan yang mereka anut dan praktikkan. Tradisi 
dan adat-istiadat setempat bagi mereka, merupakan bid'ah (sesat), yang dapat mencemarkan ajaran Islam yang sesungguhnya. Hal ini tentu berbeda dengan pemahaman mayoritas ulama Indonesia yang lebih lentur dan bijak dalam memandang tradisi. Tradisi dan adat tidak lantas dipahami sebagai sesuatu yang sesat, selagi tidak bertentangan dengan ajaran Islam, sekalipun tidak ditemukan landasan normatifnya dalam Islam. Yang dilakukan para Kiai pada umumnya adalah memasukkan nilai-nilai Islam hingga menjadi spirit dalam pengembangan dan pelaksanaan tradisi yang ada, sehingga tidak terjadi benturan antara tradisi di satu sisi, dan agama Islam di sisi yang lain. Islam sebagai agama tampil secara kreatif berdialog dengan masyarakat setempat (lokal), berada dalam posisi yang menerima tradisi masyarakat, sekaligus memodifikasinya menjadi budaya baru yang dapat diterima oleh masyarakat setempat dan masih berada di dalam jalur Islam.

Maka, dalam hal ini Islam tidak dipahami sebagai sebuah ideologi yang sarat dengan simbol-simbol Arab, yang seringkali bertindak oposisi terhadap tradisi masyarakat, tapi yang terpenting adalah agar ajaran substantif Islam dapat dipahami, diajarkan, dan dipraktikkan dalam kehidupan masyarakat. Nilai dan ajaran Islam yang substansial diberi konstruk yang berpijak pada karakteristik lokalitas dan kultural Indonesia dengan segala seluk-beluk yang mengitarinya. Nilai-nilai Islam dikontekstualisasi secara kreatif ke dalam kehidupan konkret yang dialami umat, agar dapat memenuhi tuntutan dan kebutuhan riil masyarakat (A'la, 2006: 119).

Dalam kaitannya dengan hal ini, Gus Dur menulis:

"Islam mempertimbangkan kebutuhan lokal dalam merumuskan hukum-hukum agama tanpa mengubah hukum itu sendiri. Juga bukan berarti meninggalkan norma demi budaya, tetapi agar normanorma itu menampung kebutuhan-kebutuhan dari budaya dengan menggunakan peluang yang disediakan oleh variasi pemahaman nash dengan tetap memberi peranan kepada ushul fiqh dan qaidah fiqh." (Wahid, 2001: 111)

Konsep inilah yang belakangan dikenal dengan pribumisasi Islam. Pribumisasi Islam mengupayakan agar ajaran-ajaran Islam benar-benar membumi dalam setiap ruang dan waktu yang dilaluinya. Secara sederhana, wacana pribumisasi Islam ala Gus Dur dapat dipahami sebagai upaya untuk melindungi proses asimilasi dan akulturalisasi nilai-nilai Islam dengan kebudayaan lokal Indonesia yang berlangsung secara alamiah. Upaya ini 
dilakukan dengan mengemas proses yang alamiah ke dalam tataran konsep agar tradisi-tradisi yang terbentuk dari proses asimilasi dan akulturasi ini tetap dapat diakui sebagai budaya Islami.

Bila ditelisik lebih jauh, pribumisasi Islam di Indonesia merupakan keniscayaan sejarah. Sejak awal perkembangannya, Islam Indonesia adalah Islam pribumi yang disebarkan oleh Walisongo dan para pengikutnya dengan melakukan transformasi kultural dalam masyarakat. Islam dan tradisi tidak ditempatkan dalam posisi yang berhadap-hadapan, tapi didudukkan dalam kerangaka dialog kreatif yang diharapkan terjadi transformasi di dalamnya. Proses tranformasi kultural tersebut pada gilirannya menghasilkan perpaduan di antara dua entitas: Islam dan Budaya lokal. Perpaduan inilah yang melahirkan tradisi-tradisi Islami yang hingga saat ini masih dipraktikkan dalam berbagai komunitas Islam kultural yang ada di Indonesia.

Varian Islam kultural tersebut tetap dilestarikan dan berkembang hingga hari ini. Nahdlatul Ulama (NU), sebagai organisasi sosial keagamaan yang secara geneologis lahir sebagai respon kreatif atas maraknya purifikasi Islam di berbagai wilayah di Indonesia, merupakan organisasi yang getol mempertahankan Islam kultural. Dengan kelebihan dan kekurangannya, NU telah berupaya meletakkan Islam sebagai bagian yang (nyaris) intrinsik dalam budaya masyarakat. Dengan demikian, antara Islam dan budaya lokal merupakan satu kesatuan, yang tak dapat dipisahkan, meski bisa dibedakan satu sama lain.

\section{Islam Madura: Potret Islam Kultural}

Sebagaimana dipaparkan di muka, Islam masuk dan berkembang di Madura, sebagaimana juga di Jawa melalui transformasi kultural yang dilakukan oleh para penyebar Islam. Dengan demikian, Islam yang ada dan berkembang di Madura adalah Islam kultural, yang berbasis pada tradisi masyarakat. Tradisi-tradisi lokal Madura yang sudah ada sejak zaman pra-Islam, dimodifikasi, dan kemudian disisipi nilai dan spirit Islam agar menjadi budaya yang Islami.

Tradisi-tradisi tersebut tetap lestari hingga kini. Hal ini memungkinkan lantaran pola keberagamaan yang dianut oleh masyarakat Madura berbasis pada nilai-nilai tradisi, yang dalam hal ini dikembangkan oleh Nahdlatul Ulama. NU, bagi masyarakat Madura tidak hanya dipandang sebagai organisasi sosial keagamaan, tapi lebih sebagai paham keagamaan itu 
sendiri. Ajaran-ajaran yang ditradisikan dan dipraktikkan dikalangan NU, merupakan ajaran Islam yang dianut dan dipraktikkan oleh masyarakat. Hingga pada umumnya, pada masyararakat awam, sulit membedakan antara Islam dan NU. Bahkan, ada di antara mereka yang ketika ditanya tentang agama mereka, kemudian menjawab NU. Mereka tidak menjawab Islam lantaran dalam pemahaman sederhana mereka NU adalah Islam, dan Islam adalah NU.

Fanatisme ke-NU-an masyarakat Madura membawa efek ganda dalam pola keberagamaan mereka. Satu sisi, Islam kultural dapat terpelihara dengan baik dan bahkan terlembagakan sebagai bagian integral tradisi-tradisi NU. Namun di sisi lain, umumnya mereka ekslusif terhadap paham dan ajaran Islam selain NU. Bahkan, pada derajat tertentu orang yang bukan NU dipandang sebagai orang yang tidak sempurna keislamannya. Meski demikian, fanatisme ke-NU-an tidak lantas menyulut permusuhan yang berpretensi pada tindakan anarkis.

Terhindarnya konflik yang lebih serius ini tidak lepas dari peran Kiai dalam mengarahkan dan mengatur masyarakat. Sebagaimana mafhum, Kiai merupakan kekuatan tradisional yang sangat berpengaruh dalam struktrul sosial masyarakat Madura, selain blater dan aparatur negara. Kiai, pada perkembangan selanjutnya tidak saja dipercaya dalam problem keagamaan masyarakat, tapi juga dalam bidang politik, ekonomi, dan bahkan kosmologi. Bahkan, kalangan masyarakat tertentu, menjadikan Kiai sebagai figur serba tahu dan tidak pernah salah dalam kesehariannya, sehingga apa yang diucapkannya merupakan "sabda" yang harus diikuti dan diterapkan dalam masyarakat. Posisi Kiai yang demikian strategis tersebut dengan mudah dapat mengontrol masyarakat agar tidak terlibat dalam konflik sosial yang tidak produktif. Demikian pun sebaliknya, Kiai dengan mudah dapat mengarahkan jamaahnya untuk tujuan-tujuan politis tertentu demi keuntungan yang sifatnya pragmatis (Hajar, 2009: 86).

Pengalaman sejarah menunjukkan, konflik keagamaan jarang sekali terjadi di Madura dan melibatkan etnis Madura. Konflik berdarah antara etnis Madura dan Sampit di Kalimantan misalnya, bukanlah konflik keagamaan, melainkan konflik etnis. Hal ini tidak berarti, masyarakat Madura tidak kuat dalam memegang teguh agamanya. Dalam kenyataannya, masyarakat Madura dikenal sebagai masyarakat yang religius yang tercermin dalam pola perilaku, tata pakaian, serta kondisi sosial budaya masyarakat Madura 
yang cenderung Islami. Bahkan, di Madura terdapat ribuan pesantren yang menyebar secara sporadis hingga ke pelosok desa-desa terpencil. Bahkan, hampir di setiap pedesaan Madura, selalu bercokol pesantren-pesantren, baik besar maupun kecil, yang siap mendidik anak-anak bangsa agar bisa memahami ajaran agama dengan baik. Dengan demikian, dapat dipahami tidak berkembangnya konflik keagamaan dalam masyarakat Madura bukan disebabkan karena ketidakreligiusan masyarakat Madura itu sendiri, tapi lebih karena keberagamaan mereka yang tidak pernah melepaskan tradisi. Islam berusaha masuk ke dalam budaya Madura, hingga menjadi bagian intrinsik dari budaya itu sendiri. Dan tokoh yang mempunyai peran signifikan dalam kerangka ini adalah Kiai, yang mana dalam masyarakat Madura, diposisikan sebagai penafsir atas landasan-landasan normatif Islam. Dalam melanggengkan tradisi, Kiai juga berperan signifikan, baik melalui NU sebagai organisasi, maupun melalui pesantrennya. Dalam organisasi NU, Kiai memelihara berbagai tradisi Islami tersebut melalui kompolankompolan yang melibatkan masyarakat awam, maupun dalam upacara yang sifatnya kemasyarakatan. Melalui pesantren, Kiai juga berperan dalam mewariskan dan mengajarkan tradisi-tradisi Islam tersebut kepada para santrinya melalui pembiasaan yang dilakukan secara terus-menerus setiap hari. Hal ini dilakukan agar para santri dapat menggantikan gurunya dalam menjaga dan melestarikan tradisi tersebut agar tidak serta-merta hilang dan dihapuskan oleh berbagai gerakan Islam puritan yang anti-tradisi lokal.

Ada beberapa tradisi Islam Madura yang banyak melibatkan Kiai dan komunitas santri di dalamnya. Misalnya, upacara kematian. Upacara kematian merupakan upaya mendoakan orang yang sudah meninggal agar arwahnya bisa tenang di alam barzah. Dalam upacara ini, orang yang hadir mendoakan orang yang sudah meninggal dengan membaca yasin, tahlil, atau dzikir-dzikir lain yang mana pahalanya dikhususkan pada orang yang meninggal tersebut. Selain itu, pihak keluarga juga memberikan shadaqah berupa suguhan makanan bagi para pelayat yang mendoakan, dengan harapan agar pahala shadaqah tersebut juga sampai pada arwah orang yang meninggal tersebut. Dengan dilaksanakannya upacara yang sarat dengan doa-doa ini diharapkan dosa-dosa yang sudah meninggal diampuni dan siksanya diringankan oleh Allah SWT.

Upacara kematian tidak hanya dilakukan sekali, saat hari pertama kematian itu sendiri. Upacara kematian masih dilanjutkan dengan lo' tello' 
(hari ketiga), to' petto' (hari ketujuh), pa' polo (hari keempat puluh), nyatos (hari keseratus), nyataon (satu tahun setelah kematian) dan nyaebu (hari keseribu dari kematian). Hampir tidak ada perubahan dan perbedaan berarti, dalam setiap sesi upacara kematian tersebut. Dalam setiap upacara tersebut sarat dengan tahlil, dzikir-dzikir, dan yasin. Hanya saja, bedanya, untuk lo' tello' dan to' petto', pihak keluarga tidak mengundang orang lain untuk mendoakan, tapi sebaliknya orang-orang yang datang melayat untuk mendoakan orang yang sudah meninggal tersebut. Berbeda dari itu, untuk pa' polo dan seterusnya, justru pihak keluarga yang mengundang orang-orang untuk mendoakan orang yang sudah meninggal, sesuai dengan kemampuan ekonomi keluarganya.

Perbedaan lainnya terletak pada upacara nyataon, untuk memperingati satu tahun setelah meninggalnya seseorang. Dalam komunitas kiai, apabila yang meninggal adalah Kiai atau orang yang shaleh, maka peringatan tahunan (haul) untuk selanjutnya diperingati setiap tahun, tidak hanya sekali sebagaimana yang terjadi dalam upacara kematian dalam masyarakat pedesaan. Hal ini dilakukan tidak untuk mendoakan Kiai agar tenteram di alam sana, tapi yang terpenting agar orang yang hidup, yang mendoakan tersebut dapat menerima barokah dari orang yang sudah meninggal tersebut. Sebab, penganut ahlussunnah waljama'ah percaya bahwa mendoakan orang yang shaleh, maka akan mendapat barokah dari Allah melalui perantara orang tersebut.

Tradisi lain yang akan penulis kemukakan dalam hal ini adalah pelet kandang. Pelet kandung, merupakan upacara kehamilan yang memasuki bulan ketujuh, terutama untuk anak pertama. Dalam upacara ini, suamiistri dimandikan di tengah halaman rumah dengan menggunakan air kembang tujuh rupa, sebagai sebentuk simbolisasi penyucian diri, agar anak yang lahir nantinya selamat dan benar-benar menjadi anak sholeh, yang membanggakan orang tua. Setelah mandi kembang tujuh rupa, pasangan suami-istri tersebut harus masuk ke kamar rumahnya sembari menggendong buah kelapa, yang sudah diberi nama Maryam dan Yusuf. Hal ini juga merupakan simbolisasi agar apabila anaknya kelak lahir, bila perempuan akan secantik dan sebaik maryam dan bila laki-laki akan setampan wajah yusuf. Terlepas dari itu, dalam tradisi pelet kandung ini sarat dengan doadoa dan pembacaan ayat suci. Kiai, diundang untuk memimpin doa dan membaca ayat suci al Quran. Surat-surat yang biasa dibaca adalah surat 
Yusuf, Maryam, Yasin, Muhammad dan juga memperbanyak membaca shalawat pada Nabi Muhammad SAW agar mendapat syafa'at.

\section{Perubahan Tradisi di Masyarakat Madura}

Dua tradisi lokal yang penulis hadirkan dalam kajian di atas, hingga saat ini masih dipraktikkan dalam kehidupan masyarakat Madura. Tradisitradisi tersebut masih tetap dipelihara dan dilestarikan hingga saat ini sebagai upaya untuk menjaga khazanah lokal agar tidak hilang ditelan sejarah. Namun demikian, tradisi-tradisi tersebut tidak berarti statis dan tidak berubah sama sekali. Masih ada banyak perubahan yang terjadi dalam setiap tradisi di atas, sebagai bagian dari dinamika kultural yang tak terhindarkan.

Hal ini dapat dipahami lantaran tradisi pada prinsipnya memang bukanlah suatu hal yang stagnan. Ia diwariskan dari satu generasi ke generasi selanjutnya dalam situasi, kondisi dan waktu yang berbeda dengan sebelumnya. Akibatnya, akan ada perubahan-perubahan baik dalam skala kecil atau besar. Perubahan-perubahan ini sedikitnya dipengaruhi oleh dua hal mendasar: pertama, tuntutan modernitas yang mendesak, sehingga diniscayakan adanya penyesuaian-penyeseuaian dalam tradisi itu sendiri. Kedua, tidak sempurnanya proses pewarisan tradisi dari generasi tua kepada generasi selanjutnya. Hal ini terjadi lantaran kurangnya minat generasi muda untuk mempelajari dan mempraktikkan nilai-nilai tradisi tersebut. Namun demikian, yang perlu dipahami di sini, dalam proses pewarisan, memang ada hubungan dialektik yang terjadi terus-menerus antara tradisi, masyarakat dan zaman di mana proses itu berlangsung. Antar ketiganya meniscayakan adanya dialog yang terjadi secara dinamis sehingga menghasilkan nilai-nilai dan tradisi baru yang disepakati bersama, yang sesuai dengan zaman. Dengan kata lain, perubahan, dalam derajat tertentu, merupakan keniscayaan yang tidak terhindarkan.

Kaitannya dengan dua tradisi di atas, perubahan banyak terjadi dalam simbol-simbol yang mengandung kearifan lokal di dalamnya. Dalam upacara kematian misalnya, pada mulanya, tahlil tidak akan pernah dimulai sebelum ada pembakaran kemenyan terlebih dahulu. Namun saat ini, pembakaran kemenyan tidak lagi menjadi keharusan dalam setiap upacara kematian. Upacara akan langsung dimulai, jika undangan (baca: pelayat) sudah banyak dan sang Kiai yang memimpin jalannya upacara sudah hadir 
di tengah masyarakat.

Dalam tradisi pelet kandung, ritual mandi kembang tujuh rupa dan menggendong kelapa pun sudah mulai ditinggalkan. Pada sebagian masyarakat, upacara pelet kandung dicukupkan dengan mengundang orang untuk mengaji bersama demi keselamatan anak yang ada dalam kandungan dan juga ibunya yang hamil tersebut. Selain itu, dikalangan Kiai dan komunitas santri, pelet kandung tidak hanya dilakukan pada bulan ketujuh dari kehamilan, tapi juga pada bulan keempat. Namun perbedaannya dengan pelet kandung bulan ketujuh, pada bulan keempat ini tidak ada ritual yang diambil kearifan lokal. Kecuali itu, hanya mengundang Kiai dan masyarakat untuk berdoa untuk keselamatan kehamilan, ibu, dan juga agar anak yang dilahirkan menjadi anak yang shaleh. Sebab, pada bulan keempat inilah Allah memberikan ruh pada bayi yang ada dalam kandungan, berikut dengan penentuan rezeki, jodoh, dan kematiannya. Dengan doa bersama ini, diharapkan anak yang akan lahir kelak mendapat takdir yang baik dari Allah SWT.

Perubahan-perubahan tersebut tidak terlepas dari peran Kiai di dalamnya. Ada dua cara yang dilakukan Kiai dalam hal ini. Pertama, "pembiaran". Dalam hal ini, Kiai membiarkan terjadinya kekuranglengkapan dalam suatu upacara. Semisal, tidak adanya kemenyan, tidak lantas menggagalkan terhadap jalannnya upacara, tetapi upacara tetap dilanjutkan meski tanpa adanya kemenyan. Pembiaran yang demikian pada perkembangannya mengkonstruk pemahaman masyarakat bahwa kemenyan bukan suatu hal yang pokok dalam pelaksanaan upacara. Pemahaman yang demikian pada akhirnya akan dibiasakan oleh masyarakat sehingga tradisi membakar kemenyan sebelum acara dimulai tidak lagi digunakan oleh masyarakat.

Kedua, teladan dan pembiasaan. Kiai sebagai figur ideal panutan umat, harus memberikan teladan yang baik yang dapat dicontoh. Apa yang dilakukan oleh Kiai, kaitannya dengan tradisi, merupakan "kebenaran" yang harus diikuti. Dalam tradisi pelet kandung misalnya, jika keluarga besar Kiai memulai tradisi baru berupa upacara pelet kandung sejak bulan keempat, maka masyarakat juga akan mengikuti tradisi ini. Sebab, Kiai dipandang memiliki otoritas dalam hal ini.

Dengan demikian peran Kiai dalam hal ini adalah sebagai media transformasi. Kiai dengan caranya sendiri telah melakukan trasnformasi 
kultural secara dinamis dalam masyarakat. Ini dilakukan agar dinamisasi Islam kultural dapat terjaga dengan baik.

\section{Simpulan}

Agama dan budaya lokal merupakan dua entitas yang berbeda, namun tidak harus dipertentangkan. Antara keduanya justru terdapat keniscayaan dialog yang tak terhindarkan. Agama mau tidak mau harus berdialog dengan budaya lokal agar agama tersebut diterima oleh masyarakat. Di Indonesia, dialog antara Islam dan budaya lokal menghasilkan varian Islam yang unik, khas, dan esoteris serta kaya ragam budaya. Di Madura misalnya, lahirlah Islam yang bercorak budaya Madura dengan berbagai tradisinya. Bahkan, dialektika antara Islam dan budaya lokal Madura pada perkembangan selanjutnya menghasilkan tradisi Islami yang di dalamnya antara Islam dan budaya lokal sulit dipisahkan meski bisa dibedakan.

Tradisi-tradisi tersebut tetap terpelihara hingga kini, dengan beberapa perubahan. Perubahan itu terjadi lantaran adanya dialektika yang terus-menerus antara masyarakat, tradisi, dan zaman di mana proses itu berlangsung. Perubahan-perubahan tersebut menunjukkan adanya dinamisasi Islam kultural di Madura. Bahwa, Islam yang berbasis pada nilai dan tradisi Madura bukan Islam yang statis, tapi justru dinamis sepanjang waktu. Dinamisasi tersebut dimungkinkan karena peran Kiai di dalamnya. Kiai, dalam posisi ini tidak hanya berfungsi sebagai garda terdepan dalam membela tradisi, tapi juga mengawal dan menjadi penggerak akan terjadinya dinamisasi Islam kultural dalam masyarakat Madura.

\section{Daftar Pustaka}

A'la, Abd. 2006. Pembaruan Pesantren. Yogyakarta: Pustaka Pesantren.

Al Humaidy, M. Ali. 2007. Tradisi Molodhan: Pemaknaan Kontekstual Ritual Agama Masyarakat Pamekasan, Madura. Jurnal ISTIQRO', Jurnal Penelitian Islam Indonesia, Volume 06, Nomor 01.

Aziz, Asman. 2009. Multikulturalisme: Wawasan Alternatif Mengelola Kemajemukan Bangsa, dalam Jurnal Titik-Temu, Jurnal Dialog Peradaban. Volume 2, Nomor 1, Juli-Desember. 
Azra, Azyumardi. 1982. Perspektif Islam di Asia Tenggara. Jakarta: Yayasan Obor Indonesia.

Baso, Ahmad. Asyura dan Karakter Islam Nusantara. (Online) http://konspirasi. $\mathrm{com} /$ peristiwa/asyura-dan-karakter-islam-nusantara/ diakses pada tanggal 07 September 2010.

Dhofier, Zamakhsyari dan Abdurrahman Wahid. 1978. Penafsiran Kembali Ajaran Agama; Dua Kasus dari Jombang. Jakarta: LP3ES.

Geertz, Clifford. 1981. Abangan, Santri, dan Priyayi dalam Masyarakat Jawa. Jakarta: Pustaka Jaya.

Hajar, Ibnu. 2009. Kiai Ditengah Pusaran Politik: antara Petaka dan Kuasa. Yogyakarta, IRCISOD.

Kuntowijoyo. 2001. Muslim Tanpa Masjid, Esai-Esai Agama, Budaya, dan Politik dalam Bingkai Strukturalisme Transendental. Bandung: Mizan.

Syam, Nur. 2007. Madzhab-Madzhab Antropologi. Yogyakarta: LKiS.

Thahir, Masnun. 2007. Pergumulan Hukum Islam dan Budaya Sasak: Mengarifi Fiqih Islam Wetu Telu. Jurnal ISTIQRO', Jurnal Penelitian Islam Indonesia, Volume 06, Nomor 01.

Wahid, Abdurrahman. 2009. Musuh dalam Selimut sebuah pengantar pada buku Ilusi Negara Islam: Ekspansi Gerakan Islam Transnasional di Indonesia. Jakarta: The Wahid Institute bekerjasama dengan Gerakan Bhinneka Tunggal Ika dan Maarif Institute.

Wahid, Abdurrahman. 2001. Pergulatan Negara, Agama, dan Kebudayaan. Jakarta: Desantara. 